Vol. 15 (2006): 340-349.

\title{
Phenotypic and genetic parameters and responses in temperament of silver fox cubs in a selection experiment for confident behaviour
}

\author{
Hilkka Kenttämies and Marja Nikkilä \\ Department of Animal Science, PO Box 28, FI-00014 University of Helsinki, Finland, \\ e-mail: hilkka.kenttamies@animal.helsinki.fi \\ Maija Miettinen \\ Siikasalmi Research Station, Fur Farm of the University of Joensuu, present address: \\ Finnish Fur Breeders Association, PO Box 5, FI-01601 Vantaa, Finland \\ Juha Asikainen \\ University of Joensuu, Department of Biology, PO Box 111, FI-80101 Joensuu, Finland
}

\begin{abstract}
A selection experiment for more confident silver foxes was arranged to find out possibilities to obtain selection response in confidence. Variation in aggressiveness and ease of capture was also studied. Fixed factors affecting the traits were studied using WSYS program. Covariances for breeding values were estimated with REML and multitrait animal models using VCE4 and Pest programs. It appeared that males were more confident than females. Cubs born in small litters tended to be more confident, less aggressive and easier to capture compared to those born in greater litters. Cubs of one-year-old dams seemed to be more confident and easier compared to those of older dams. Moderate estimate of heritability was obtained for confidence $\left(h^{2}=0.22\right)$. During three years of selection, genetic response of 0.13 points was achieved in confidence in selection line compared to control line. A higher selection differential existed in males than females. Predicted response of 0.21 points was slightly higher than the estimated one. No heritability was observed in aggressiveness, while a low one existed in ease of capture $\left(h^{2}=0.07\right)$. No association between confidence and the other behaviour traits were found.
\end{abstract}

Key words: welfare, foxes, confidence, aggressiveness, ease of capture, selection response

\section{Introduction}

Improvement of welfare is one of the most important goals in ethical and economical animal farm- ing. Fear of humans may induce stress in animals. Stress is partly resulting from hormonal differences (Belyaev 1979, Plyusnina et al. 1991, Popova et al. 1991, Osadschuk 1992, Bakken et al. 1994, Plyusnina et al. 1996, Rekilä et al. 1999). Hormo- 
Vol. 15 (2006): 340-349.

nal secretion is notably due to gene action. Hormonal changes have been observed simultaneously with genetic changes in behaviour. In foxes selected for confidence (CB) or tameness, a decrease in stress hormones (Plyusnina et al. 1991, Osadschuk 1992, Plyusnina et al. 1996, Rekilä 1999) and an increase in tryptophan (precursor of serotonin) (Plyusnina et al., 1991, Popova et al., 1991) have been established. In animals selected for enhanced aggressiveness towards human, increase in defensive responses (fear and aggression) was associated with a significant rise in plasma cortisol level. However, no defensive responses or changes in plasma cortisol level were observed in domesticated foxes (Plyusnina et al. 1991). Popova et al. (1991) demonstrated that the increased serotonin secretion in foxes is associated with the domestication mechanism of wild aggressive / defensive animals into tame ones.

In domestic animals, genetic variation for different kinds of behaviour has been reported (e.g. Siegel 1975, Grandin and Deesing 1998, Vangen et al. 2002). Genetic parameters for behaviour traits in fur animals have been presented only in a few studies. In the 1960s, a tame fox was developed in Russia using genetic selection (Belyaev 1979). Inspired by the Russian experiences, possibilities to improve welfare of farm foxes by selecting for confidence towards humans were studied in a Nordic project "Selection for more confident foxes". In Finland and Norway studies were done on farms and on selection experiments with blue foxes and silver foxes (FFBA 1995). Based on data from 30 Finnish farms, Nikula et al. (2000) found moderate heritability estimates in CB in blue fox and silver fox adults and cubs. In studies with blue foxes selected for CB in Finland and Norway, a positive selection response was achieved (Kenttämies et al. 2002). Similar result was obtained also with silver foxes in a corresponding study in Norway (Nordrum et al. 2002). Selection experiments for behaviour in mink revealed evidence of genetic variation in CB or curiosity (Hansen 1996, Hansen et al. 2000), and a positive selection response was also attained (Berg et al. 2002).

Aggressive behaviour (AG) of animals towards herd mates and farm keepers is considered as a harmful trait, especially in group farming. Therefore the most aggressive individuals are often eliminated from the herd. Plyusnina et al. (1991) found that animals without defensive characteristic are easier to capture compared to aggressive or fearful ones. In Russian silver foxes selected for tame behaviour, the effect of early handling was hardly visible while a positive effect was obvious among unselected animals (Popova et al. 1991). Such genetic variation in these temperament traits would enable selection for or against the trait.

The main objectives of the present study with silver fox cubs was to discover if selection for $\mathrm{CB}$ towards humans produces selection response, and if change in $\mathrm{CB}$ coincides with changes in $\mathrm{AG}$ and ease of capture (EC). The importance of the genetic and environmental factors affecting the behaviour traits was studied as well.

\section{Material and methods}

\section{Experimental design}

In 1995 to 1999, a selection experiment with silver foxes was done at Siikasalmi Research Station Fur Farm of the University of Joensuu. The animals were fed and managed according to standard farm routines. Most of the cubs were housed in individual cages supplied with resting platforms and wooden biting sticks. Artificial insemination was used in producing new generations. Pedigree and reproduction data were reported in Sampo, the Finnish fur animal breeding program. In December, the appearance of the cubs was subjectively graded using a scale from 1 to 5 , where 5 denoted the best or largest or lightest end of the scale. The same person performed the gradings each year. And because of severe genetic anomalies or defects in some families and occasionally destroyed identification cards. Such individuals or families were discarded from the population.

In 1995, animals were obtained for the experiment from the research station itself and in addition from six private farms. The imported cubs 
Kenttämies, $H$. et al. Phenotypic and genetic parameters and responses in temperament of silver fox

were progeny of one-year-old dams and sires apart from those coming from a neighbouring farm closing the farming. Cubs from the same or related litters within each farm were divided into two similar groups according to tested CB (FFBA 1995). In 1996, cubs for the following generation were mostly progeny from mating the females originating from one farm by a male from another farm. In selection line (SL) selection was based only on breeding value (EBV) of CB. Low whelping result throughout the study, partly due to a great number of young females selected for breeding, decreased selection intensity. There were also differences between original farms in reproductive performance. In addition, manifestation of severe anomalies and diseases decreased vitality of animals. In control line (C) selection was based on total merit index that was obtained by summing the EBVs for litter size, body size, underfur density, guard hair density and colour and colour clarity after weighing the litter size EBV by 0.4 and the other production trait EBVs' by 0.15 , respectively. In order to retain genetic variation in the control line, at least one female cub from each dam and one male cub from each sire were included in the next generation. Selection was continued within the closed lines. Inbreeding was avoided by refraining from mating between full and half sibs, and maximum 2-3 cubs from the same litter were selected for breeding.

In 1995, the foundation stock consisted of 306 animals from which 269 males and females were yearlings. From 1996 to 1999 there were altogether 1569 cubs tested for confidence. In 1998 and 1999, 913 cubs were also tested for AG, and in 1997 to 1999,812 cubs were tested for EC. In
1999 the activities in the farm were finished and behaviour tests of animals, particularly EC, were mostly done on progeny of young dams only. Therefore analyzing data was at first done on cubs of young dams. Numbers of cubs tested for CB and sires and dams within each year and line are given in Table 1.

\section{Evaluation of behaviour traits}

Confidence was tested using a feeding test described and validated by Rekilä et al. (1997). A scale from 1 to 3 points was used where 3 denotes confident animal (eats within $30 \mathrm{~s}$ when the experimenter is standing in front of the cage avoiding eye contact with animals), 2 denotes a less confident/less fearful (eats immediately after the experimeter has moved to the next cage), and 1 denotes fearful (does not eat while the experimenter is standing in front of that or of the next cage). The testing was done for each animal in the middle of October 4 times within 2-4 days. The mean of the 4 successive tests denoted the final score for CB.

Aggressiveness was tested using a stick test as described by Plyusnina et al. (1991) and Rekilä (1999). These tests were done for each animal in October 4 times within 1-3 weeks, after all cubs were tested for CB. An ascending 7 - point scale from 1 to 7 was used where 7 denotes tame animal (shows no aggressiveness). Point 6 denotes rather tame (stands when approaching the cage, bites the stick after opening the cage and touching the animal with the stick). Point 5 denotes less tame (bares the teeth when approaching, bites harder

Table 1. Numbers of male $\left(\sigma^{7}\right)$ and female (\$) cubs tested for confidence, sires and dams of each line from 1996 to 1999.

\begin{tabular}{|c|c|c|c|c|c|c|c|c|c|c|c|c|}
\hline \multirow[t]{3}{*}{ Year } & \multicolumn{6}{|c|}{ Selection line } & \multicolumn{6}{|c|}{ Control line } \\
\hline & \multicolumn{2}{|c|}{ Cubs } & \multicolumn{2}{|c|}{ Sires } & \multicolumn{2}{|c|}{ Dams } & \multicolumn{2}{|c|}{ Cubs } & \multicolumn{2}{|c|}{ Sires } & \multicolumn{2}{|c|}{ Dams } \\
\hline & $0^{\pi}$ & ᄋ & 1 year & $>1$ year & 1 year & $>1$ year & $0^{\pi}$ & ㅇ & 1 year & $>1$ year & 1 year & $>1$ year \\
\hline 1996 & 72 & 78 & 14 & 1 & 35 & 8 & 95 & 84 & 7 & 2 & 44 & 9 \\
\hline 1997 & 77 & 72 & 10 & 3 & 28 & 11 & 76 & 65 & 12 & 3 & 28 & 11 \\
\hline 1998 & 136 & 142 & 19 & 1 & 47 & 28 & 123 & 95 & 20 & 3 & 39 & 23 \\
\hline 1999 & 117 & 113 & 17 & 1 & 43 & 16 & 123 & 101 & 19 & 1 & 39 & 17 \\
\hline
\end{tabular}


than above-mentioned). Point 4 denotes slightly tame (like above but bites the stick growling). Point 3 denotes slightly aggressive (growls when approaching the cage, bites the stick with aggressiveness). Point 2 denotes rather aggressive (like 3 but snaps at air and attacks towards the tester). The lowest score (1) denotes aggressive animal (croaks, bares the teeth when seeing a human, pupils flared, don't allow to open the cage). The mean of the 4 successive tests denoted the final score for AG.

Ease of capture was evaluated once when capturing the cubs for grading in December. This test developed and described by Asikainen (personal communication in 1997), expresses how the animal responds to an acute situation when captured. Validity of EC can be expected to be high during capture. In this situation animals are forced to choose their acute reaction against captor. The situation is new for these young silver fox cubs. An ascending scale from 1 to 5 points was used. Point 5 denoted very easy and included animals, which responded with tonic immobility to catching. Very easy (5) and easy (4) included animals, which were submissive or responded with tonic immobility. Ordinary behaving (not strongly defensive, evading or biting), confident silver foxes got 3 points. Difficult (2) and very difficult (1) to catch included animals, which behaved in defensive, aggressive and attacking way and attempted to bite on captor. Or quite the contrary, also the animals escaping or hiding strongly denoted difficult responses.

\section{Statistical analyses}

Editing of data and testing of significance of fixed factors were done with program WSYS - L (Vilva 1999). The effects of following fixed factors were studied on CB, AG and EC; year; line; interaction between year and line; sex of the cub; litter size class and age of the dam. Covariance components were estimated with the Restricted maximum likelihood (REML) -method applied to single and multiple trait models using VCE 4.0 program and used in PEST program for finding breeding values.

\section{Variance and covariance components}

In estimating variance and covariance components for $\mathrm{CB}, \mathrm{AG}$ and $\mathrm{EC}$, the following model was used:

$$
\begin{aligned}
\mathrm{y}_{\mathrm{ijk} k \mathrm{mn}}= & \mu+\text { year }_{\mathrm{i}}+\text { sex }_{\mathrm{j}}+\text { litter size of } \text { dam }_{\mathrm{k}}+ \\
& \text { age of dam } \mathrm{dam}_{1}+\mathrm{a}_{\mathrm{m}}+\mathrm{li}_{\mathrm{n}}+\varepsilon_{\mathrm{ijklmno}}
\end{aligned}
$$

where $\mathrm{y}_{\mathrm{ijklmn}}=\mathrm{CB}, \mathrm{AG}$ and $\mathrm{EC}, \mu=$ overall mean, year $_{i}=$ fixed effect of the $i^{\text {th }}$ year $(i=1, \ldots, 4$ for $C B$; $\mathrm{i}=1,2$ for $\mathrm{AG} ; \mathrm{i}=1, \ldots, 3$ for $\mathrm{EC}$, sex $_{\mathrm{j}}=$ fixed effect of the $\mathrm{j}^{\text {th }}$ sex class $(1=$ male, $2=$ female $)$, litter size of dam $_{\mathrm{k}}=$ fixed effect of the $\mathrm{k}^{\text {th }}$ litter size class $(1=$ $1, \ldots, 3 ; 2=4,5 ; 3=6, \ldots, 8$ cubs per dam at 2 weeks), age of dam $_{1}=$ fixed effect of the $1^{\text {th }}$ age class of dam ( $1=1$ year old, $2=$ older than 1 year $)$, $\mathrm{a}_{\mathrm{m}}=$ random additive genetic effect of the $\mathrm{m}^{\text {th }}$ animal, $\mathrm{li}_{\mathrm{n}}=$ random effect of the $\mathrm{n}^{\text {th }}$ litter, and $\varepsilon_{\mathrm{ijk} k \mathrm{mno}}$ $=$ random residual effect. The distributions of $\mathrm{a}, \mathrm{li}$ and $\varepsilon$ were assumed to be multivariate normal with zero means and with $\operatorname{Var}(\mathrm{a})=\mathbf{A} \sigma^{2}$, $\operatorname{Var}(\mathrm{li})=\mathbf{I} \sigma^{2}$, and $\operatorname{Var}(\varepsilon)=\mathbf{I} \sigma_{\varepsilon}^{2}$, and $\operatorname{Cov}(\mathrm{a}, \mathrm{li})^{\mathrm{a}}=\operatorname{Cov}(\mathrm{a}, \varepsilon) \stackrel{\mathrm{li}}{=}$ $\operatorname{Cov}($ li, $\varepsilon)=0$, where $\mathbf{A}=$ a matrix of additive relationship among animals, $\mathbf{I}=$ an identity matrix and $\sigma^{2} \sigma_{\text {al }}^{2}$ and $\sigma_{\varepsilon}^{2}$ are variance components for additive genetic, litter and residual effects. The estimates of heritability $\left(\mathrm{h}^{2}\right)$ and litter effect $\left(\mathrm{c}^{2}\right)$ were defined as follows:

$$
\begin{aligned}
& \mathrm{h}^{2}=\sigma_{\mathrm{a}}^{2} /\left(\sigma_{\mathrm{a}}^{2}+\sigma_{\mathrm{li}}^{2}+\sigma_{\varepsilon}^{2}\right) \\
& \mathrm{c}^{2}=\sigma_{\mathrm{li}}^{2} /\left(\sigma_{\mathrm{a}}^{2}+\sigma_{\mathrm{li}}^{2}+\sigma_{\varepsilon}^{2}\right)
\end{aligned}
$$

The models described above were used for estimating (co)variance components between $\mathrm{CB}$ and $\mathrm{AG}$ and $\mathrm{CB}$ and $\mathrm{EC}$. In estimating heritabilities and breeding values a single trait model was applied for each trait. In these estimations the effect of line was not taken in account.

\section{Predicted and estimated selection responses}

Predicted selection responses in CB between lines within year were calculated using the following 
Kenttämies, H. et al. Phenotypic and genetic parameters and responses in temperament of silver fox

formula: $\Delta \mathrm{G}=\mathrm{r}_{\mathrm{TI}} * \mathrm{i} * \partial_{\mathrm{a}}$ where $\Delta \mathrm{G}=$ predicted response, $\mathrm{r}_{\mathrm{TI}}=$ accuracy of prediction, $\mathrm{i}=$ selection intensity, $\sigma_{\mathrm{a}}=$ additive genetic standard deviation. Rearranging and reducing the terms in the formula gives: $\Delta \mathrm{G}=\mathrm{i} * \sigma_{\mathrm{I}}$ where $\sigma_{\mathrm{I}}=$ standard deviation of the index (Falconer and Mackay 1996, p. 244). Selection intensity was defined as selection differential when using original units (points). The effective selection differential was based on the phenotypic means of confidence for the selected males and females in comparison with the corresponding total means. The selected males and females appeared as parents of the following generation.

Realised genetic changes in $\mathrm{CB}$ within each year and line were calculated as a deviation of estimated breeding values from the start of the experiment (Falconer and Mackay 1996). Phenotypic changes were obtained by comparing the Least Squares estimates within year and line.

\section{Results and discussion}

\section{Phenotypic changes in confidence}

During the experiment, no significant differences between lines within years appeared in CB. In
1996 when no selection had yet been done, $39 \%$ of the cubs in the SL and $37 \%$ of the cubs in C came to eat in the first test within 30 seconds, indicating that these animals feel no fear towards a human. In the third selection generation (1999), similar proportion of the cubs in both lines (31 in SL vs. 37\% in C) came to eat in the first evaluation. The corresponding proportions of the fearful cubs (did not come to eat within 30 seconds or when the experimenter was standing in front of the next cage) were in the beginning 35 vs. $42 \%$ and at the end of the study 33 vs. 29\%. The corresponding figures in cubs of one-year-old dams were much the same. Thus no systematic differences between lines within years were seen in the proportion of confident or fearful animals. The same was evident also in AG and EC. Arithmetic means for CB, AG and EC points were unaltered (Table 2). In the total material, the average inbreeding rates of cubs were $1.7 \%$ in SL and $1 \%$ in C.

\section{Fixed effects for the behaviour traits}

In order to study the effect of farm on $\mathrm{CB}$, cubs of one-year-old dams and sires originating from different farms were compared. In data from 1996 when no selection had yet been done, slight differ-

Table 2. Arithmetic means and standard deviations (SD) for points of confidence, aggressiveness and ease of capture in the total data and within lines from 1996 to 1999.

\begin{tabular}{|c|c|c|c|c|c|c|c|c|}
\hline \multirow[t]{2}{*}{ Trait } & \multicolumn{2}{|c|}{1996} & \multicolumn{2}{|c|}{1997} & \multicolumn{2}{|c|}{1998} & \multicolumn{2}{|c|}{1999} \\
\hline & Mean & SD & Mean & SD & Mean & SD & Mean & SD \\
\hline \multicolumn{9}{|l|}{ Confidence } \\
\hline All data & 2.29 & 0.71 & 2.05 & 0.72 & 1.80 & 0.69 & 2.24 & 0.69 \\
\hline Selection line & 2.32 & 0.67 & 2.02 & 0.71 & 1.85 & 0.69 & 2.28 & 0.68 \\
\hline Control line & 2.26 & 0.75 & 208 & 0.74 & 1.75 & 0.69 & 2.20 & 0.70 \\
\hline \multicolumn{9}{|l|}{ Aggressiveness } \\
\hline All data & & & & & 5.28 & 0.96 & 5.13 & 1.05 \\
\hline Selection line & & & & & 5.20 & 1.00 & 5.21 & 1.04 \\
\hline Control line & & & & & 5.36 & 0.90 & 5.37 & 0.90 \\
\hline \multicolumn{9}{|l|}{ Ease of capture } \\
\hline All data & & & 3.14 & 0.87 & 2.81 & 1.15 & 2.87 & 1.03 \\
\hline Selection line & & & 3.18 & 0.94 & 2.90 & 1.19 & 2.86 & 1.12 \\
\hline Control line & & & 3.10 & 0.81 & 269 & 1.10 & 2.87 & 0.93 \\
\hline
\end{tabular}


Vol. 15 (2006): 340-349.

ences between progeny from various farm combinations in $\mathrm{CB}$ occurred $(\mathrm{P}=0.052)$. Due to mostly mating females with a male descending from another farm, the effect of original farms on CB was not taken in analyses in account. No significant interaction between year and line or systematic changes within each line occurred in the behaviour traits.

In all data and within each line, male cubs were found to be more confident than female cubs $(\mathrm{P}<$ $0.001)$. This agrees with earlier studies with blue fox and silver fox cubs (Nikula et al. 2000, Kenttämies et al. 2002, Nordrum et al. 2002). In this study, no differences between male and female cubs were observed in AG or EC. Plyusnina et al. (1991) also found no differences between sexes in behaviour of silver foxes selected for defensive or tame behaviour or in control. Korhonen and AlaSuutari (1995) observed that blue fox males usually dominate over females of the same age, partly due to differences in body size and hormonal aspects.

In the present study, cubs of yearling dams were more confident than those of the older dams $(\mathrm{P}<0.001$ in all data and $\mathrm{C}$, and $\mathrm{P}<0.01$ in $\mathrm{SL})$. Cubs of young dams seemed to be easier to capture $(\mathrm{P}<0.08$ in all data and $\mathrm{P}=0.06$ in SL) while no differences were found in $\mathrm{C}$. In all data, cubs born in small litters (1-3 cubs per litter) tended to be more confident $(\mathrm{P}<0.01)$, less aggressive $(\mathrm{P}<$ $0.09)$ and easier to capture $(\mathrm{P}<0.05)$ compared with those born in larger litters, and the most fearful, aggressive and difficult cubs came from the largest litters (6-8 cubs). No differences between litter size groups were found in $\mathrm{CB}$, while slight differences were noticed in AG $(\mathrm{P}<0.09)$ and $\mathrm{EC}$ $(\mathrm{P}<0.06)$. In control, differences between litter size groups were observed in $\mathrm{CB}(\mathrm{P}<0.001)$ and EC $(\mathrm{P}<0.07)$. The effect of number of sibs on confidence was also found in the Norwegian studies with blue fox and silver fox cubs (Kenttämies et al. 2002, Nordrum et al. 2002).

\section{Heritability for confident behaviour}

A moderate heritability estimate with low standard error was achieved for CB $\left(h^{2}=0.22 \pm 0.05\right)$. In addition, a low litter effect appeared $\left(c^{2}=0.15 \pm\right.$ 0.02 ), suggesting that there also existed other than additive genetic variation (Table 3 ). Similar estimates were found in data containing only cubs of one-year-old dams. In previous studies with foxes, low to moderate heritabilities and moderate repeatabilities in confidence have been reported (Nikula et al. 2000, Kenttämies et al. 2002, Nordrum et al. 2002).

\section{Heritability for confident behaviour within lines}

Low to moderate estimates of heritability for $\mathrm{CB}$ were obtained within each line $\left(\mathrm{h}^{2}=0.09 \pm 0.08\right.$ in SL vs. $h^{2}=0.37 \pm 0.08$ in C) (Table 3 ). In cubs of young dams, similar estimate for $\mathrm{CB}$ appeared in SL, while a higher one existed in $C\left(\mathrm{~h}^{2}=0.58 \pm\right.$ $0.08)$. In each group the corresponding variances for permanent environment were low $\left(c^{2}=0.13\right.$ to

Table 3. Estimates of heritability $\left(\mathrm{h}^{2}\right)$ and litter effect $\left(\mathrm{c}^{2}\right)$ with standard errors (SE), additive genetic $\left(\sigma_{\mathrm{a}}^{2}\right)$, litter $\left(\sigma_{\mathrm{l}}^{2}\right)$ and environmental variances $\left(\sigma_{\mathrm{e}}^{2}\right)$ for confidence of silver fox cubs in all data, selection line and control line.

\begin{tabular}{lccccc}
\hline Trait & $\mathrm{h}^{2} \pm \mathrm{SE}$ & $\mathrm{c}^{2} \pm \mathrm{SE}$ & $\sigma_{{ }_{\mathrm{a}}}$ & $\sigma^{2}{ }_{1}$ & $\sigma^{2}{ }_{\mathrm{e}}$ \\
\hline Confidence & & & & & \\
$\quad$ All data & $0.22 \pm 0.05$ & $0.15 \pm 0.02$ & 0.104 & 0.070 & 0.310 \\
$\quad$ Selection line & $0.09 \pm 0.08$ & $0.15 \pm 0.04$ & 0.043 & 0.070 & 0353 \\
Control line & $0.37 \pm 0.08$ & $0.13 \pm 0.03$ & 0.191 & 0.068 & 0.252 \\
\hline
\end{tabular}

Tested from ${ }^{\mathrm{a}} 1996$ to 1999 
Kenttämies, H. et al. Phenotypic and genetic parameters and responses in temperament of silver fox

0.15). Low additive variance for confidence in SL may partly be due to reduced genetic variation caused by selection (Falconer and Mackay 1996). Similar effect of selection was also found in a corresponding Finnish study with blue foxes (Kenttämies et al. 2002) while in the respective Norwegian study with silver foxes, the estimates within the two breeding goals (selected for confidence vs. traditionally bred) were much the same (Nordrum et al. 2002).

\section{Selection intensity for confident behaviour}

Each year, 13 to $25 \%$ of male cubs and 30 to $65 \%$ of female cubs of the SL were selected as parents of the following generation. In $\mathrm{C}$, the corresponding proportions were on average $17 \%$ of males and $43 \%$ of females. In SL, the phenotypic superiority of the selected male cubs over all male cubs tested in the same year in $\mathrm{CB}$ varied yearly from 0.24 to 0.86 points. In females, the corresponding difference varied from 0.12 to 0.22 points (Table 4$)$. On an average, the phenotypic selection differential was 0.56 points in males and 0.13 points in females, the effective selection differential being 0.342 points. Confidence of the control males selected for breeding was on average 0.12 points higher than that of all male cubs in the line, while no difference was observed in control females.

\section{Selection response in confidence}

From the second selection generation onwards, response was found in CB in SL while no visible progress existed in $\mathrm{C}$ (Fig. 1). After selecting for $\mathrm{CB}$ for three years, a genetic improvement of 0.13 points was attained in SL, while very low change (0.02 points) appeared in C compared to the starting point. Thus in three years a total selection response of 0.15 points was gained. The predicted response in the SL, based on the effective selection differential of 0.39 points and the standard deviation of the index of 0.19 was predicted to be 0.07 points per year. The selection differential increased especially in males in the third selection year. During three years of selection, the corresponding cumulated response was 0.21 points. However, the increase in $\mathrm{CB}$ in SL was not manifested in the phenotypic values. In previous selection experiments for tame or confident behaviour with silver foxes in Russia and Norway (Belyaev 1979, Nordrum et al. 2002) and with blue foxes in Finland and Norway (Kenttämies et al. 2002), phenotypic selection responses for the trait under selection were attained. In the Russian silver foxes and Finnish blue foxes, phenotypic differences between the selected and control animals were visible within first two generations (Belyaev 1979, Kenttämies et al. 2002).

Due to the restricted selection possibilities in the first two years, the experiment was originally aimed to continue for further one or two years but unfortunately all activities in the farm were totally finished in 1999. In the Norwegian selection experiment with silver foxes, an annual response of 0.2 points (on a 6 point scale) was attained in the line selected for confidence for four years, while no genetic change appeared in the traditionally bred line (Nordrum et al. 2002). In the corresponding selection experiments in Finland and Norway

Table 4. Proportion of selected from all male and female cubs and the phenotypic differences between the selected and all silver fox males and females in confidence from 1996 to 1998.

\begin{tabular}{lcccc}
\hline Year & \multicolumn{2}{c}{ Proportion selected } & \multicolumn{2}{c}{$\begin{array}{c}\text { Phenotypic selection differences in } \\
\text { confidence }\end{array}$} \\
& Males & Females & Males & Females \\
\hline 1996 & 13.9 & 35.9 & 0.24 & 0.22 \\
1997 & 23.4 & 66.7 & 0.63 & 0.12 \\
1998 & 13.2 & 30.3 & 0.86 & 0.22 \\
\hline
\end{tabular}


Vol. 15 (2006): 340-349.

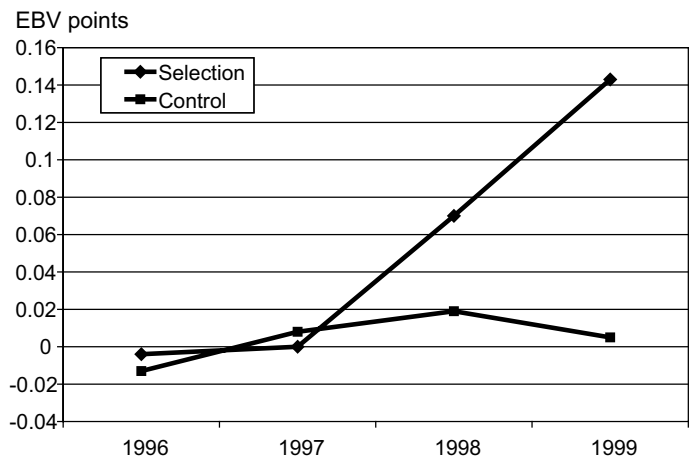

Fig. 1. Selection responses for confidence in silver foxes selected (Selection) or not selected (Control) for confidence. $\mathrm{EBV}=$ estimated breeding value.

done with blue foxes, larger response was obtained in Norway compared to Finland, mainly due to a greater selection differential in males (Kenttämies et al. 2002).

\section{Genetic parameters for aggressiveness and ease of capture}

In AG, very low heritability and a low litter effect $\left(c^{2}=0.18 \pm 0.02\right)$ were found in the total data set. In EC, the corresponding figures were low to moderate $\left(h^{2}=0.07 \pm 0.07\right.$ and $\left.c^{2}=0.21 \pm 0.04\right)$. The low and varying estimates obtained for AG and EC may partly be explained by the small and heterogeneous samples in these two traits compared to those obtained for CB. The fairly occasional testing of $\mathrm{AG}$ and $\mathrm{EC}$ was due to the fact that these traits were not included in the original project plan. However, in a sample from 1998, a phenotypic accuracy of testing was found to be similar in CB and AG (Kenttämies and Miettinen 1999).

Genetic and phenotypic correlations between confidence and the other behaviour traits tended to be either very low or non-existent (data not presented). Therefore possible changes in AG and EC along with changes in $\mathrm{CB}$ could not be observed.

\section{Conclusions}

A selection experiment for confident behaviour in silver foxes illustrates a possibility of obtaining genetic response in this trait. During three years of selection, the predicted and estimated responses in confident behaviour in the selection line were much the same. However, the genetic increase in confident behaviour was not manifested in the phenotypic values. Additive genetic variation essential for successful selection was found in confident behaviour and ease of capture, while no genetic variation was observed in aggressive behaviour. In order to reach genetic improvement, effective selection of breeding animals, especially of males should be emphazised. The moderate permanent environmental variances in the three studied traits indicate that the behaviour of the mother and the cage mates at an early stage has an effect on the later behaviour of the animal. Apart from genetic differences, fixed factors like the sex of the cub, the litter size of the dam, and the age of the dam largely explained the differences in behaviour of silver foxes. No correlation was observed between confidence and the other studied behaviour traits. However, there was a genetic tendency for confident animals to be easier to capture but slightly more aggressive than fearful ones.

Acknowledgements. The project was initiated in cooperation with the Finnish Fur Breeders' Association and the Universities of Helsinki, Joensuu and Kuopio. We had prof. Mikko Harri, Institute of Applied Biotechnology, University of Kuopio to thank for planning the testing scheme of confident behaviour. Prof. Matti Ojala, Department of Animal Science, University of Helsinki, is appreciated for interest and valuable discussions. Veijo Vilva, Department of Animal Science, University of Helsinki, is given warm thanks for technical assistance and discussions throughout the experiment. Dr. Anna-Elisa Liinamo is thanked for reading and proposing corrections in the first manuscript. Sanna Nikula, Department of Animal Science, University of Helsinki, is acknowledged for editing files for adults and cubs. Kerstin Smeds, the Finnish Fur Breeders Association is acknowledged for interest and valuable help in supplying animals from practical farms for the foundation stock. We thank the research assistants of Institute of Applied Biotechnology, University of Kuo- 
Kenttämies, H. et al. Phenotypic and genetic parameters and responses in temperament of silver fox

pio, especially for Dr. Teppo Rekilä for giving guidance and performing confidence measurements at the start of the experiment. Taina Leinonen and Matti Heiskanen are thanked for carefully feeding and managing animals and for doing matings. Barne Nyholm is thanked for carefully evaluating of the appearance traits of the cubs. Students of the Department of Animal Science, University of Helsinki are thanked for entering data into computer. Financial support was given from the Finnish Fur Breeders' Association.

\section{References}

Bakken, M., Braastad, M.O., Harri, M., Jeppesen, L.L. \& Pedersen, V. 1994. Production conditions, behaviour and welfare of farm foxes. Scientifur 18: 233-248.

Belyaev, D.K. 1979. Destabilizing selection as a factor in domestication. Journal of Herededity 70: 301-308.

Berg, P., Hansen, B.K., Hansen, S.W. \& Malmkvist, J. 2002. Both direct and indirect genetic effects influence behavioural response in mink. In: Elsen, J.-M. \& Durcocq, V. (eds.). Proceedings from the 7th World Congress on Genetics Applied on Livestock Production. CD-ROM communication no. 14-02. ISBN 2-7380-1052-0.

Falconer, D.S. \& Mackay, T.F.C. 1996. Introduction to quantitave genetics. 4th Edition. Longman, New York, 464 p. ISBN 0582-24302-52.

FFBA 1995. Project plan. The Finnish Fur Breeders Association, Vantaa, Finland. $9 \mathrm{p}$

Grandin, T. \& Deesing, M.J. 1998. Behavioural genetics and animal science. In: Grandin, T. (ed.). Genetics and the behaviour of domestic animals. Academic Press, London. p. 1-30.

Hansen, S.W. 1996. Selection for behavioural traits in farm mink. Applied Animal Behaviour Science 49: 137-148.

Hansen, B.K., Berg, P., Hansen, S.W. \& Malmkvist, J. 2000. Genetic parameters for behavioural traits in farm mink. In: Proceedings of the 51st Annual Meeting of the European Association for Animal Production. The Hague, The Netherlands, 21 - 24 August 2000. Book of abstracts p. 25.

Kenttämies, H. \& Miettinen, M. 1999. Tarhattujen kettujen hyvinvointia parannetaan valitsemalla luottavaisia eläimiä. In: Bioproducts for the next millenium. University of Helsinki, Lectures and Poster Abstracts in the Jubilee Seminar of the Faculty of Agriculture and Forestry. p. 47. ISBN 951-45-8884-3.

Kenttämies, H., Nordrum, N., Valberg, Brenöe, U.T., Smeds, K., Johannessen, K. J. \& Bakken, M. 2002. Selection for more confident foxes in Finland and Norway: heritability and selection responses for confident behaviour in blue foxes (Alopex lagopus). Applied Animal Behaviour Science 78: 67-82.
Korhonen, H. \& Ala-Suutari, S. 1995. Dominance relations in captive groups of adult and juvenile arctic blue foxes. Polar Biology 15: 353-358.

Nikula, S., Smeds, K., Hietanen, H., Kenttämies, H. \& Ojala, M. 2000. Confident behaviour and production traits Results from a field study. In: Murphy, B.D. \& Lohi, O. (eds.). Proceedings from the 7th International Congress in Fur Animal Production. Part III - B Genetics, Kastoria, Greece 13 - 15 September 2000. Scientifur Vol. 24, No.4. p. 99-102.

Nordrum, N., Valberg, Brenöe, U.T., Johannessen, K. J. \& Bakken, M. 2002. Selection response for confident behaviour in silver foxes (Vulpes vulpes) and correlated responses in the production traits. In: Reports from NJF Seminarium no. 347. Vuokatti, Finland, 2-4 October 2002. 11 p. ISSN 0333-1350.

Osadschuk, L.V. 1992. Genetic and endocrine aspects in the regulation of the reproduction function in silver fox. In: Skrede, A. (ed.). Proceedings from the 5th International Congress in Fur Animal Production. Norwegian Journal of Agricultural Sciences Supplement No. 9: 161-166.

Plyusnina, I.Z., Oskina, I.N. \& Trut, L.N. 1991. An analysis of fear and aggression during early development of behaviour in silver foxes (Vulpes vulpes). Applied Animal Behaviour Science 32: 253-268.

Plyusnina, I.Z., Oskina, L. \& Trut, L. 1996. Selection of silver foxes for domesticated behaviour with reference to their welfare. In: Frindt, A. \& Brozozowski, M. (eds.). Proceedings from the 6th International Congress in Fur Animal Production. Progress Fur Animal Science. Polish Society of Animal Sciences. Animal Production Review 29: 17-21.

Popova, N.K., Voitenko, N.N., Kulikov, A.V. \& Augustinovich, V.F. 1991. Evidence for the involvement of central serotonin in mechanism of domestication of silver foxes. Pharmacology, Biochemistry \& Behaviour 40: 751-756.

Rekilä, T. 1999. Behavioural tests in welfare research of foxes. Kuopio University Publications C. Natural and Environmental Sciences 92: 1-52.

Rekilä, T., Ahola, L. \& Harri, M. 1997. Validation of the feeding test as an index of fear in farmed blue (Alopex lagopus) and silver foxes (Vulpes vulpes). Physiology \& Behavior 62: 805-810.

Rekilä, T., Harri, M., Jalkanen, L. \& Mononen, J. 1999. Relationship between hyponeophagia and adrenal cortex function in farmed foxes. Applied Animal Behaviour Science 65: 779-783.

Siegel, P.B. 1975. Behavioural genetics. In: Hafez, E.S.E. (ed.). The behaviour of domestic animals. Williams \& Wilkins, Baltimore, MD. p. 20-42.

Vangen, O., Holm, B., Rossly, T., Vasbotten, M., Valros, A. \& Rydhmer, L. 2002. Genetic variation in maternal behaviour of sows. In: Elsen, J.-M. \& Durcocq, V. (eds.). Proceedings from the 7th World Congress on Genetics Applied on Livestock Production. CD-ROM communication no. 14-12. ISBN 2-7380-1052-0.

Vilva, V. 1999. WSYS - L program package. Department of Animal Science, University of Helsinki, Finland. Available on the Internet: http://www.animal.helsinki.fi/guide/. 


\title{
SELOSTUS
}

\section{Hopeaketun luonteenpiirteiden fenotyyppiset ja geneettiset tunnusluvut sekä muutokset pentujen luottavaisuuteen}

\author{
Hilkka Kenttämies, Marja Nikkilä, Maija Miettinen ja Juha Asikainen \\ Helsingin yliopisto ja Joensuun yliopisto
}

Valintakokeella pyrittiin selvittämään, voidaanko hopeaketun pennun ihmistä kohtaan tuntemaa luottavaisuutta pysyvästi parantaa. Samalla tutkittiin myös aggressiivisuuden ja käsiteltävyyden vaihtelua.

Luottavaisuus oli testattu kaikkiaan 1569, aggressiivisuus 913 ja käsiteltävyys 812 pennulta. Valintalinjassa pennut valittiin luottavaisuuden jalostusarvon perusteella, kontrollilinjassa luottavaisuutta ei otettu huomioon eläimiä valittaessa. Koe kesti viisi vuotta ja valinta kolmen vuoden ajan.

Urospennut olivat luottavaisempia kuin naaraspennut. Pienissä pentueissa syntyneet pennut vaikuttivat luottavaisemmilta, vähemmän aggressiivisilta ja helpommilta käsitellä kuin keskikokoisissa ja suurissa pentueissa syntyneet pennut. Yksivuotiaiden emojen pennut näyttivät olevan luottavaisempia ja helpompia käsitellä kuin vanhempien emojen pennut. Luottavaisuus osoittautui kohtalaisesti periytyväksi. Käsiteltävyyden ja aggressiivisuuden periytymisasteet olivat pieniä tai olemattomia, mutta pentuevaikutukset olivat kohtalaisia. Valintalinjan pentujen luottavaisuuden jalostusarvo kohosi 0,13 arvostelupistettä enemmän kuin kontrollilinjassa. Vanhemmiksi valittujen eläinten fenotyyppiseen paremmuuteen ja indeksin hajontaan perustuva edistyminen oli valintalinjassa hieman todettua edistymistä suurempi (0,21 pistettä). Fenotyyppistä edistystä ei havaittu. Muissa tutkituissa luonneominaisuuksissa ei näkynyt muutoksia kummassakaan linjassa. Luottavaisuudella ja muilla luonneominaisuuksilla ei ollut keskinäistä yhteyttä. Keinosiemennysurosten luottavaisuuden testaamista ja valintaa suositellaan tarhattujen kettujen hyvinvoinnin edistämiseksi. 
